\title{
Is Door-to-Door Canvassing Effective in Europe? Evidence from a Meta-study across Six European Countries
}

\author{
YOSEF BHATTI, JENS OLAV DAHLGAARD, JONAS HEDEGAARD HANSEN \\ AND KASPER M. HANSEN*
}

\begin{abstract}
A vast amount of experimental evidence suggests that get-out-the-vote encouragements delivered through door-to-door canvassing have large effects on turnout. Most of the existing studies have been conducted in the United States, and are inspiring European mobilization campaigns. This article explores the empirical question of whether the American findings are applicable to Europe. It combines existing European studies and presents two new Danish studies to show that the pooled point estimate of the effect is substantially smaller in Europe than in the United States, and finds no effects in the two Danish experiments. The article discusses why the effects seem to be different in Europe compared to the United States, and stresses the need for further experiments in Europe as there is still considerable uncertainty regarding the European effects. While one possible explanation is that differences in turnout rates explain the differences in effect sizes, the empirical analysis finds no strong relationship between turnout and effect sizes in either Europe or the United States.
\end{abstract}

Keywords: mobilization; turnout; get out the vote; door-to-door canvassing; meta-study

To what extent do campaigns to increase voter turnout affect the likelihood of participation? This question has received considerable attention in the academic literature, especially since Gerber and Green's seminal field experiments in New Haven, Connecticut. ${ }^{1}$ Perhaps one of the most studied mobilization tools is door-to-door canvassing, which is widely used in US campaigns. ${ }^{2}$ In a recent review of the literature, Green, McGrath and Aronow $^{3}$ identified seventy-one canvassing experiments with a precision-weighted average complier average causal effect (CACE) ${ }^{4}$ of 2.536 percentage points and a 95 per cent credible interval of $(1.817,3.255)$. The effect of door-to-door

* Danish Institute for Local and Regional Government Research (email: yobh@kora.dk); Department of Political Science, University of Copenhagen (emails: jod@ifs.ku.dk, jhh@ifs.ku.dk and kmh@ifs.ku.dk/www.kaspermhansen.eu). The authors thank the volunteers in Copenhagen and Randers for participating in the two doortwo-door experiments, Jens Kristian Rasmussen for coordinating the effort in Randers, and Mariann Malchau Olsen and Ane Reese Mikkelsen for excellent research assistance. They thank Donald P. Green, Florian Foos, Frederik Hjorth and participants at the Danish Political Science Association's Annual Meeting 2015 for valuable comments. This project was supported by the Danish Council for Independent Research (grant no. 12-124983). Data replication sets are available at http://dataverse.harvard.edu/dataverse/BJPolS and online appendices are available at https://doi.org/10.1017/S0007123416000521.

${ }^{1}$ Gerber and Green 2000.

2 E.g., Bedolla and Michelson; Gerber and Green 2000; Green, Gerber, and Nickerson 2003; Matland and Murray 2012; Nickerson 2008; Enos and Fowler 2016.

3 We do not consider American studies conducted after Green, McGrath, and Aronow (2013).

4 The CACE is the average effect among those who take the treatment if and only if assigned to it (i.e., compliers). In the literature (e.g., Angrist, Imbens and Rubin 1996, 448) it is also referred to as the LATE effect (Local Average Treatment Effect) (Gerber and Green 2012, 142). 
canvassing is one of the largest and most robust in the get-out-the-vote (GOTV) literature and almost rivals the effect from social pressure mailings. ${ }^{5}$

A few published studies have focused on the effectiveness of door-to-door canvassing outside the United States. Guan and Green ${ }^{6}$ mobilized students in a 2003 Beijing election, John and Brannan $^{7}$ canvassed British voters in the 2005 election, and Giné and Mansuri ${ }^{8}$ targeted female voters in rural Pakistan. The three studies observed varying levels of effects, from modest to impressive. The relative efficiency of door-to-door canvassing, and to some extent inspiration from the 2008 Obama campaign, ${ }^{9}$ has led to its increased popularity outside the United States. For example the Danish Social Democrats relied heavily on this strategy in the 2011 general election after campaign strategists had volunteered on the Obama campaign. ${ }^{10}$ However, most studies concerning the effect of door-to-door canvassing are focused on the US context, which has prompted some skepticism regarding the generalizability of the results to Europe as European campaigns adopt US strategies. Following John and Brannan, ${ }^{11}$ several (currently unpublished) studies from across Europe find mixed results. ${ }^{12}$ This article compiles evidence related to door-to-door canvassing in Europe and presents findings from two new studies conducted in the context of a Danish election.

Studying the effects of door-to-door canvassing in Europe is interesting for at least three reasons. First, in several European countries turnout is much higher than in the United States, especially considering that many of the existing American studies target voters in low-salience elections. This means a ceiling effect might occur in Europe, as there is less scope for door-to-door campaign mobilization than in the United States.

Secondly, there could be cultural differences. Door-to-door canvassing is more frequently used in the United States than in most European countries, apart from perhaps the UK. ${ }^{13}$ This means that voters in Europe are not as used to being exposed to political messages on their doorstep, and they might find it invasive to be confronted with political campaigns at their front door. European canvassers and canvassing organizations are also simply less experienced than many US canvassing organizations that have built up experience in a number of elections. This might lead to less influential door-to-door-campaigns in Europe. ${ }^{14}$

Thirdly, institutional differences might vary the impact of door-to-door campaigns. Most US studies are conducted in first-past-the-post systems, which are considerably more candidate focused than most ${ }^{15}$ European proportional representation (PR) systems. It is possible that this makes doorstep conversations more relevant and effective in the United States compared to Europe (setting Britain aside for a moment) because it is possible to have more relevant and engaging discussions about the character of individual candidates, whereas in countries like Denmark discussions would have to be more abstract and focus on parties. ${ }^{16}$ Furthermore, US studies are often conducted in competitive districts where the chance of being pivotal is

${ }^{5}$ Green, McGrath, and Aronow 2013.

${ }^{6}$ Guan and Green 2006.

7 John and Brannan 2008.

${ }^{8}$ Giné and Mansuri 2011.

9 Pons 2016, 6.

10 Jason and Kollerup 2014.

11 John and Brannan 2008.

12 Cantoni and Pons 2016; Foos and John 2016; Nyman 2014; Pons 2016; Pons and Liegey 2016; Ramiro, Morales, and Jiménez-Buedo 2012.

${ }^{13}$ Karp, Banducci, and Bowler 2007.

${ }^{14}$ Ramiro, Morales, and Jiménez-Buedo 2012.

${ }^{15}$ However, see for instance Bengtsson et al. (2014) for a discussion of the diversity among systems.

${ }^{16}$ We would like to thank one of the reviewers for this point. 
especially high, which might also increase the effectiveness of campaigns even if an individual's vote, on average, has greater leverage in a PR system. Another institutional difference is the need for registration in the United States, which, among other things, provides canvassers with information about individuals who are motivated to vote and their party affiliation. This might lead to more effective campaigns.

In total, the compiled theoretical arguments point in the direction of smaller effects in Europe. Yet ultimately it is an empirical question. In this article, we compile evidence from published and unpublished door-to-door canvassing experiments in Europe and present two new studies from Denmark. The main finding from a meta-analysis is that the average effect of European studies is well below the mean effect from the United States. In fact, though the point estimate is positive at 0.78 percentage points, based on the studies conducted so far it is still too early to say whether door-to-door canvassing is an effective strategy in Europe at all. The confidence interval (CI) of the estimate is $(-0.16,1.71)$, so it cannot be ruled out either that the effect is quite substantial. We emphasize that this conclusion is in part due to a limited number of studies - many of which have low power, including our own. This does not change the fact that at this point the best estimate is that door-to-door canvassing is not the same silver bullet in Europe as in the United States, but that more research is needed.

\section{DOOR-TO-DOOR STUDIES IN EUROPE}

\section{Existing Literature}

To our knowledge, the only published study that examines the effectiveness of door-to-door canvassing in Europe is John and Brannan's ${ }^{17}$ study of the 2005 British general election. The experiment included 2,510 individuals and found an intention-to-treat (ITT) effect of 3.6 percentage points for the non-partisan canvassing and a CACE of 6.7, with a standard error of 3.7 .

In recent years, several additional high-quality (currently unpublished) studies have been conducted. Ramiro, Morales and Jiménez-Buedo ${ }^{18}$ conducted a partisan campaign in the Spanish city of Murcia during the 2011 local elections. They found negative treatment effects, though the exact size of the CACE is unclear due to uncertainty about the compliance rate. Therefore, this study will not be included in the meta-analysis.

Pons and Liegey ${ }^{19}$ studied 23,773 citizens sampled at the building level in the 2010 French regional elections and reported an effect of 0.4 percentage points with a standard error of 0.8 on voting in the first round of the elections from living in a building treated by the partisan campaign.

Also in France, Pons ${ }^{20}$ conducted a door-to-door canvassing experiment in co-operation with Hollande's 2012 presidential campaign. The study encompassed 2,660 precincts. Due to imperfect compliance by the canvassers, Pons ${ }^{21}$ suggests scaling the CACE with a factor of 2.2. This gives a CACE estimate of 0.5 percentage points with a standard error of 0.7 .

A recent study of the 2014 European Parliament election in Sweden analyzes partisan canvassing among 10,897 individuals. ${ }^{22}$ It demonstrates an ITT effect of 2.3 percentage points and a CACE of 3.6 percentage points with a standard error of 1.9 .

17 John and Brannan 2008.

18 Ramiro, Morales, and Jiménez-Buedo 2012.

19 Pons and Liegey 2016.

20 Pons 2016.

21 Pons 2016.

22 Nyman 2014 
Foos and John ${ }^{23}$ present a study of partisan door-to-door canvassing in the British European Parliament elections in 2014. Voters who received a leaflet and an attempt was made to contact them were 3.7 percentage points less likely to vote than voters in the control group. They estimate a CACE of -8.5 percentage points and a standard error of 4.3 . $^{24}$

Finally, ${ }^{25}$ Cantoni and Pons ${ }^{26}$ had volunteers and candidates canvass voters in one municipality in Italy's European and municipality elections of 2014. They found that volunteers increased turnout, while candidates failed to produce an effect. The volunteer canvassers had an ITT of 1.8 percentage points, while the effect for the candidates was -0.2 percentage points. The contact rates were 35.9 and 45.5 per cent, respectively. When we convert the ITTs to the $\mathrm{CACEs}^{27}$ and weigh them by their precision, we get a pooled CACE of 2.7 percentage points with a standard error of 1.7 .

\section{New Studies from Denmark}

In addition to the existing studies, we present two experiments conducted in the 19 November 2013 Danish municipal elections. Danish municipal elections are held simultaneously every fourth year on the third Tuesday of November in ninety-eight municipalities. Each municipality is one multimember district, in which mandates are distributed proportionally by D'Hondt's rule and candidates run on either semi-open or open lists. The national political parties dominate the municipal councils, though local lists have some influence in a minority of the municipalities. Even though municipal elections do not receive the same level of attention as national elections, and the elections may be considered as second order, it is fair to say that the municipalities are an important part of the public sector in Denmark. The public sector is very decentralized and municipalities have the authority to levy taxes under restrictions from the central government and administer about 30 per cent of the entire GDP. Turnout usually fluctuates around 70 per cent. In 2013, the national average was 71.9 per cent with considerable variation between the municipalities from 61.2 per cent turning out to vote in Copenhagen to 85.4 per cent on the small island municipality of Fanoe; 5.3 per cent of the votes cast were early votes.

Data on voter turnout stems from the voter lists. All eligible voters are automatically registered. When citizens vote, they are marked on the voter lists. Some municipalities use electronic voter lists, and voters are marked by scanning the barcode on the polling card. After the election, we collected the voter files from all ninety-eight municipalities. Where manual lists were used, the municipalities digitized them before submitting them for research. While a few lists were lost due to administrative errors at the polling places, we gained access to individuallevel turnout information for about 99 per cent of all eligible citizens (4.36 million individuals). The voter lists were then matched with information on treatment status from the experiments, and finally were anonymously merged with detailed socio-demographic information from Statistics Denmark, the government statistics bureau. ${ }^{28}$

23 Foos and John 2016.

24 We are grateful to Florian Foos for providing these estimates.

25 Braconnier, Dormagen, and Pons (2016) study the effect of canvassing on voter registration and subsequent turnout in France. However, in a European context, voter registration is an unusual requirement for voting. Thus we find that their study does not conform with representative European GOTV studies. Therefore we do not include it in the meta-analysis.

26 Cantoni and Pons 2016.

27 We divide the IIT by the contact rate. Usually this would give a consistent estimate of the CACE (Gerber and Green 2012, 151).

28 Bhatti et al. 2014a; Hansen 2016. 


\section{Study 1: Non-partisan Mobilization in Copenhagen}

'We Vote Together' (in Danish 'Vi stemmer sammen') was a non-partisan door-to-door canvassing campaign run by researchers from the University of Copenhagen (the authors). The campaign was carried out the weekend before election day. In the experiment, a randomly selected treatment group of households received visits from two canvassers recruited mainly among current and former students at the University of Copenhagen. The canvassers were volunteers, primarily students, and received a brief introduction to the project and the randomized design as well as a short script. The canvassers went over the script but did not rehearse it. They were told that they were free to do the canvassing as they pleased and that the script was for inspiration. They were required to encourage people to vote and hand out a flyer at the door. They were also instructed not to leave flyers with voters who did not open the door.

The selected group of interest was 3,402 households in the Østerbro neighborhood in the capital, Copenhagen. All voters in a household were assigned the same treatment status as the household. The area's turnout was average for Copenhagen but below the national turnout level. ${ }^{29}$ The target population was divided into eighteen routes. Each route consisted of 189 households; ninety were randomly selected to the treatment group and ninety-nine to the control group. In total, 1,620 households with 2,167 eligible citizens were selected to the treatment group, whereas 1,782 households with 2,345 citizens were in the control group; 36 per cent of the households in the treatment group were successfully contacted. The ITT was -0.8 percentage points. A consistent estimator for the CACE is to divide the ITT by the contact rate. ${ }^{30}$ That gives a CACE of -2.1 percentage points with a standard error of 4.6. A more elaborate description of the results is available in the online appendix.

\section{Study 2: Mobilization by Labor Market Union in Randers}

A local youth branch of one of the largest labor market unions in Denmark (3F Ungdom, Randers) launched a door-to-door mobilization campaign before the election. The target group was the youth organization's own members, who were all between eighteen and thirty years of age. Canvassers were trained to introduce themselves at the door, and to listen and establish a pleasant conversation. They were instructed to deliver an appeal in two parts: first, to encourage voting and tell the voter why it was important to the canvasser that some of the candidates elected would work to promote issues of interest to the youth labor market union and its members. Secondly, the voters were offered a list of forty-seven recommended candidates from a broad spectrum of the running parties. A total of 194 candidates ran in the municipality.

Randomization was carried out at the household level to overcome issues of withinhousehold spillover. The randomization was based on the organization's member list, which contained the same personal identifier that was in the general public records. This made it straightforward to merge the file with the above-described turnout data. As the treatment directly targeted individual citizens, only members of the organization are considered in the experiment. Other voters who resided at the same address are not considered as part of either the treatment or control group. A few households contained more than one member of the organization. We randomly selected 440 households (454 eligible citizens) to the treatment group, whereas the control group consisted of 439 households (451 eligible citizens). Canvassers were instructed to ask for the member in question, but if anyone in the household

29 In the control group, 61.8 per cent turned out compared to 71.9 in the country at large.

30 Gerber and Green 2012, 151. 
opened the door it was considered treated. In the few multimember households, only the person answering the door was generally involved in the conversation.

The contact rate, defined as anyone in the household answering the door, was 24 per cent. The ITT was -3.8 percentage points. Due to the low contact rate the CACE is estimated to be -15.4 percentage points, however the standard error is 13.9 , which can be ascribed to a combination of the limited sample size and relatively low contact rate. Once again, we refer to the online appendix for a more elaborate description.

\section{META-ANALYSIS}

In Table 1, we compile evidence from the previous studies and the two new studies. In addition to the scarcity of European experiences, we notice that all the studies are from Western Europe. This limitation is worth keeping in mind as we evaluate the compiled evidence. We can combine the studies for which we have an estimate of the CACE in a fixed-effects meta-analysis. ${ }^{31}$ The precision-weighted average of the CACE is 0.78 percentage points with a 95 per cent CI from -0.16 to 1.71 percentage points. The point estimate is well below the general point estimate from the American literature. If we exclude John and Brannan's ${ }^{32}$ (UK) study from the meta-analysis reported by Green, McGrath and Aronow, ${ }^{33}$ the precision-weighted estimate for the American studies is 2.50 percentage points with a 95 per cent CI of $(1.77,3.22)$. A simulation-based test of the difference between the distributions gives a p-value of 0.002 when testing if the American estimate is greater than the European. ${ }^{34}$ This difference between the European and American studies is even without Ramiro, Morales and Jiménez-Buedo, ${ }^{35}$ who found a negative effect estimate but did not include a CACE estimate that can easily be implemented in the meta-analysis.

The European CI is considerably wider than that of the CI from the American literature, reflecting the small number of European studies to date. There is thus a need for further studies in a European context. In Figure 1, we have compiled all the studies included in the European meta-analysis along with the pooled European and American estimates. The figure confirms that we cannot infer with certainty that the effect in Europe is positive; nor can we be certain that the effect is indeed smaller than in the United States, especially because the European results depend on a few large-scale studies. Keeping these uncertainties in mind, the best estimate is still that there is a small and positive effect, though it is substantially smaller than what has been observed in the United States.

The meta-analysis ignores any heterogeneity between the effects. One might question the external validity, and whether we can even compare effects from relatively diverse countries as France, Sweden, Britain, Italy and Denmark. The p-value for a test of the heterogeneity of the effects is 0.062 , suggesting that there might be some heterogeneity in effects that future studies

${ }^{31}$ Gerber and Green 2012, 361

32 John and Brannan 2008.

33 Green, McGrath, and Aronow 2013.

${ }^{34}$ We ran a simulation test in which we took a draw from each of two normal distributions with means and standard errors equal to the European and American CACE estimates, respectively. We repeated this 1,000,000 times to find that in just 0.2 per cent of the draws, the draw from the European distribution was greater than the draw from the American distribution. In the notes for Table 1, we highlight that we could alternatively arrive at a different estimate if we change our assumptions concerning Pons and Liegey (2016) and Pons (2016). If we base our evaluation on the larger and more imprecise estimate of 1.56 with a standard error of 0.78 , in 13.9 per cent of our draws the estimate for Europe is greater than for the United States. Thus while it is clear that the point estimate is lower in Europe, we cannot conclude with certainty that the effect is smaller than in the United States.

${ }^{35}$ Ramiro, Morales, and Jiménez-Buedo 2012. 


\begin{tabular}{|c|c|c|c|c|c|}
\hline Study & Context & $\mathrm{CACE}^{\mathrm{a}}$ (st. error) & $\begin{array}{l}\text { Control group } \\
\text { turnout }(\%)\end{array}$ & Total N & $\begin{array}{l}\text { Contact } \\
\text { rate }(\%)\end{array}$ \\
\hline John and Brannan (2008) & $\begin{array}{l}\text { Households in one constituency in British } 2005 \\
\text { general election }\end{array}$ & $\begin{array}{c}6.7 \\
(3.7)\end{array}$ & 46.3 & 2,510 & 54 \\
\hline $\begin{array}{l}\text { Ramiro, Morales and } \\
\text { Jiménez-Buedo (2012) }\end{array}$ & One city in 2011 Spanish local elections & $\begin{array}{l}\text { Not reported. } \\
\text { ITT }=-1.6^{\mathrm{b}}\end{array}$ & 67.5 & 26 census sections & - \\
\hline Pons and Liegey (2016) & $\begin{array}{l}\text { Citizen clustered by building in eight cities in French } \\
2010 \text { regional election }\end{array}$ & $\begin{array}{c}0.4 \\
(0.8)^{\mathrm{c}}\end{array}$ & 34.2 & $\begin{array}{l}23,773 \text { voters clustered in } \\
1,347 \text { buildings }\end{array}$ & 49 \\
\hline Pons (2016) & $\begin{array}{l}\text { Nationwide with treatment by precinct in French } \\
2012 \text { presidential election }\end{array}$ & $\begin{array}{l}0.5 \\
(0.7)^{\mathrm{c}}\end{array}$ & 80.8 & 2,660 precincts & 48 \\
\hline Nyman (2015) & $\begin{array}{l}\text { One county in } 2015 \text { Swedish European Parliament } \\
\text { election }\end{array}$ & $\begin{array}{l}3.6 \\
(1.9)\end{array}$ & 45.3 & 10,897 & 63 \\
\hline Foos and John (2016) & 2014 British European election in one constituency & $\begin{array}{l}-8.5 \\
(4.3)\end{array}$ & 30.7 & 6,127 & 42.9 \\
\hline Cantoni and Pons (2016) & $\begin{array}{l}2014 \text { Italian Municipality and European election in } \\
\text { one municipality }\end{array}$ & $\begin{array}{c}2.7 \\
(1.7)\end{array}$ & 74.7 & 26,352 & $\begin{array}{l}45.5 \\
35.9^{d}\end{array}$ \\
\hline $\begin{array}{l}\text { Bhatti et al. (2014b), } \\
\text { Copenhagen }\end{array}$ & 2013 election in Copenhagen municipality & $\begin{array}{l}-2.1 \\
(4.6)\end{array}$ & 61.8 & 4,512 & 36 \\
\hline Bhatti et al. (2014b), Randers & 2013 election in Randers municipality & $\begin{array}{l}-15.4 \\
(13.9)\end{array}$ & 53.6 & 904 & 24 \\
\hline Meta-analysis & & $\begin{array}{l}0.78 \\
(0.48)\end{array}$ & & & \\
\hline
\end{tabular}

${ }^{\mathrm{a}}$ Percentage points. ${ }^{\mathrm{b}}$ Standard errors not reported. ${ }^{\mathrm{c}}$ Canvassers did not strictly adhere to the experimental protocol which is taken into account in the calculation of the CACE. For Pons and Liegey (2016) we use the IV estimate accounting for this and for Pons (2016) we use the recommended imperfect compliance multiplier of 2.2. We do not adjust for non-complying households because non-compliers were provided with treatment material. However, if we do so anyway, the pooled effect increases to 1.56 (standard error 0.78 ). ${ }^{\mathrm{d}}$ Cantoni and Pons (2016) randomly assign households to volunteer and candidate canvassers and only report separate effects. The CACE for volunteer canvassers is 5.0 with a standard error of 2.2 . The effect for candidate canvassers is -0.4 with a standard error of 2.6. The table presents a precision-weighted average of the CACE and its standard error. The contact rates are split for candidates and volunteers, the latter in italics. 


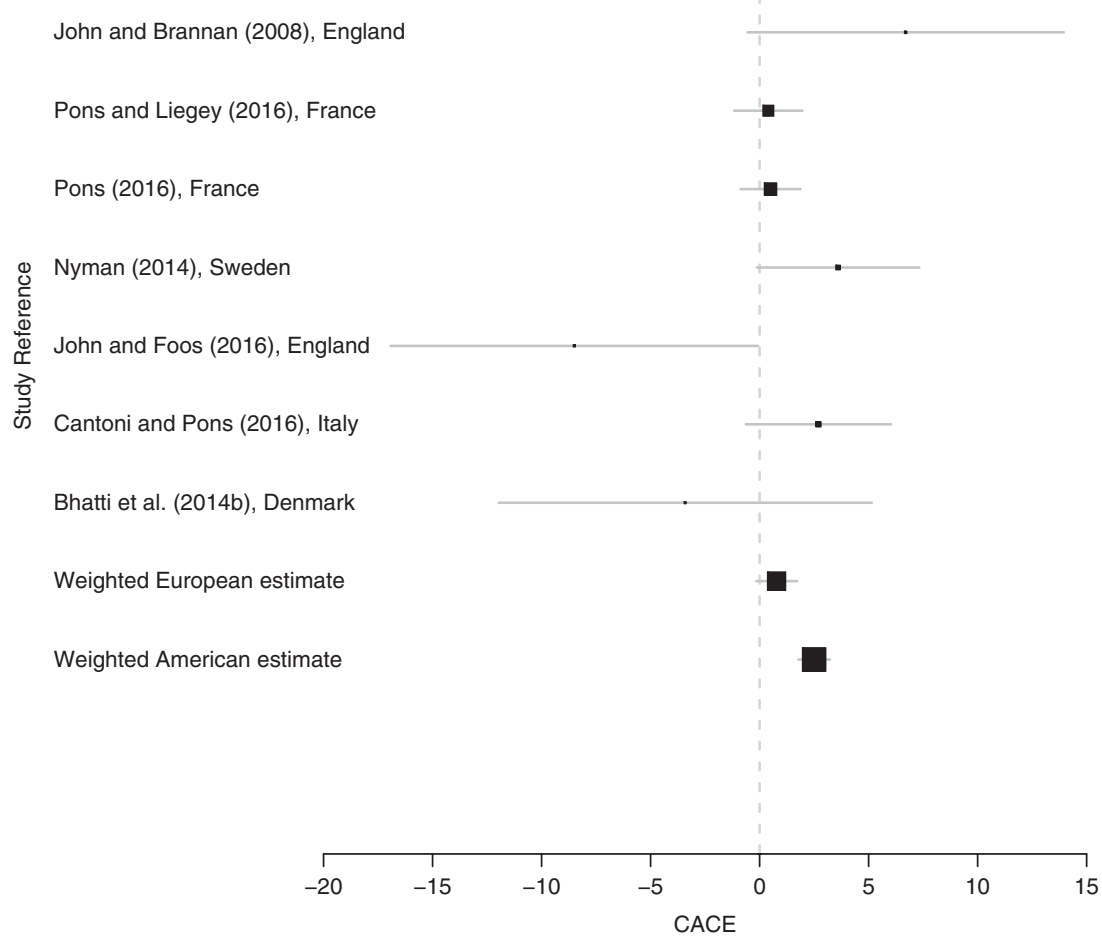

Fig. 1. Estimates from European studies and pooled European and American estimates Note: the bars are the 95 per cent CIs. The box is centered at the best estimate and its area is scaled by its precision.

can explore. Though Fieldhouse et al. ${ }^{36}$ find that geographical context moderates effects in a population-based experiment using mailings and phone calls in Britain only to a limited extent, there could be heterogeneity across countries.

One source of heterogeneity could be salience or turnout levels. This could also help explain the smaller effects in Europe. Turnout in many of the elections in question is at least comparable to a high-turnout American election. Above we suggested that one of the reasons we might not expect effects similar to those in the United States is that the results could be subject to a ceiling effect. To examine this possibility, we plot the CACEs against the control groups' turnout rates in Figure 2. The size of each point is proportional to the estimate's precision. Furthermore, the fitted line is from a regression of CACE on control group turnout weighted by precision. Figure 2 reveals a practically flat relationship between turnout in the control group and the effect size. However, control group turnout rates are not randomly assigned. Thus we cannot be certain whether effects in contexts with low turnout rates would change if these places suddenly increased overall turnout. ${ }^{37}$

36 Fieldhouse et al. 2014.

37 Green and Geber $(2008,174)$ find a curvilinear relationship between control group turnout and the effect of mobilization from US door-to-door campaigns, suggesting that it is harder to mobilize in very low and very high 


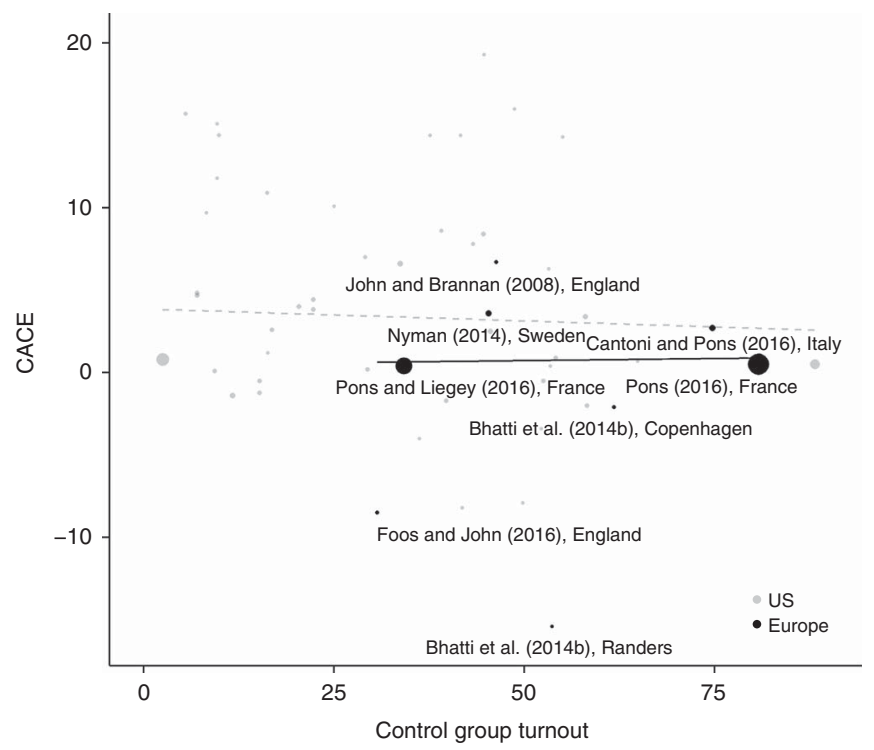

Fig. 2. Relationship between control group turnout and effect size

Note: the points are scaled by their precision (one divided by the variance) and the regression lines are from weighted least squares regressions with precision of point estimates as regression weights.

We have also gone back to the US door-to-door studies included in the Green, McGrath and Aronow meta-analysis and added control group turnout to their dataset where it was missing. ${ }^{38}$ This allows us to analyze the relationship between CACE and turnout in the US setting. The gray markers in Figure 2 are the US studies. The analysis finds a very weak negative relationship in these US studies, suggesting that initial turnout level is weakly negative related to the effect of door-todoor campaigns. Though the evidence is weak, there is a negative correlation between control group turnout and effect size, at least in the United States. Thus we cannot rule out the possibility that differences in turnout levels are driving part of the differences in effect size. Yet the regression line for the United States is above the European line at all levels of turnout in the control group. It is interesting that the largest CACE is found in the only first-past-the-post election among the European studies, suggesting that election systems might correlate with the effects of door-to-door canvassing, but with only one election we cannot draw any definitive conclusions.

\section{DISCUSSION}

This article contributes to the literature by compiling evidence from seven previous European studies and two new studies. Including our two studies, we obtain a precision-weighted average CACE of 0.78 percentage point with a 95 per cent CI from -0.16 to 1.71 percentage points.

\section{(F'note continued)}

turnout settings with door-to-door campaigns. We tested for a curvilinear relationship (our model diverges from Green and Gerber's) and found a similar curvilinear relationship between the number of contacts per vote and the control group's turnout rate in both the European and American data. However, the relationships in our models fall short of statistical significance with the European data and are marginally statistically significant in the American data.

${ }^{38}$ We were able to find control group turnout for fifty (mean turnout 33.9 per cent, SD 20.0) of the US studies and add this variable to Green, McGrath, and Aronow's (2013) original dataset. Replication data is available at http://dataverse.harvard.edu/dataverse/BJPolS. 
In other words, the current best estimate based on experiences from Western Europe is below the general estimate, but is positive as in the United States. Although our findings are fragile, we think it is important to summarize both the published and non-published evidence at the current stage to help practitioners and scholars who are conducting GOTV research to plan campaigns based on all the available evidence. ${ }^{39}$ A large amount of money and volunteers' time are spent based on the existing research, and this important addition might make some European campaigns reconsider their tactics or at least think about how to measure the impact of their efforts.

However, while these results might suggest that canvassing is less effective in Europe than the United States, the findings cannot be taken as final proof that canvassing is ineffective in European elections. Instead, we need more experiments in order to more precisely estimate the effectiveness of door-to-door canvassing in Europe and to verify whether the US results can be applied to a European context. While the collective literature on European door-to-door canvassing effects has progressed in recent years, there are still substantial uncertainties. In addition, we have only estimated the effect on overall mobilization. Campaigns might still benefit from door-to-door canvassing by demobilizing out-party voters, ${ }^{40}$ persuading voters to support their party ${ }^{41}$ or only mobilizing low-propensity voters. ${ }^{42}$

There could be numerous potential explanations of the difference between the general positive effects of door-to-door canvassing in the United States and the smaller effects in Europe that we have presented here. The generally higher turnout in Europe might be part of the explanation (a so-called ceiling effect), combined with the fact that most European elections are conducted using PR systems. In the United States, we need stronger evidence of the effectiveness of door-to-door canvassing in battleground states vs. non-battleground states, on registered voters vs. non-registered voters, on partisan vs. non-partisan appeals, and on canvassing conducted by candidates vs. volunteers.

Common wisdom in the American context is that door-to-door canvassing, though resource intensive, has a sizable effect on turnout. If nothing else, our article demonstrates that researchers and practitioners should be cautious about assuming that lessons from a USdominated field can be transferred to their own countries' contexts. The compiled evidence we presented here demonstrates that more research is needed before we accept this to be the case in Europe. Finally, we discuss evidence from six Western European countries. The effect of doorto-door canvassing in the rest of Europe is a question for further investigation.

\section{REFERENCES}

Angrist, Joshua D., Guido W. Imbens, and Donald B. Rubin. 1996. Identification of Causal Effects Using Instrumental Variables. Journal of the American Statistical Association 91 (434):444-55.

Bedolla, Lisa G., and Melissa R. Michelson. 2012. Mobilizing Inclusion: Transforming the Electorate through Get-Out-The-Vote Campaigns. New Haven, CT: Yale University Press.

Bengtsson, Åsa, Kasper M. Hansen, Ólafur Th. Harðarson, Hanne M. Narud, and Henrik Oscarsson. 2014. The Nordic Voter: Myths of Exceptionalism. Colchester: ECPR Press.

Bhatti, Yosef, Jens Olav Dahlgaard, Jonas Hedegaard Hansen, and Kasper Møller Hansen. 2014a. Hvem stemte og hvem blev hjemme? - Valgdeltagelsen ved kommunalvalget 19. november 2013. Beskrivende analyser af valgdeltagelsen baseret på registerdata [Who Voted and Who Stayed at

39 Franco, Malhotra, and Simonovits 2014.

40 Foos and John 2016.

41 Cantoni and Pons 2016; Foos 2016.

42 Bhatti et al. 2014c; Bhatti et al. 2015. 
Home? - Voter Turnout at the November 19, 2013 Municipal Elections. Descriptive Analyses of Voter Turnout based on Register Data], Working Paper No. 2/2014, Copenhagen: Center for Voting and Parties,Department of Political Science, University of Copenhagen.

2014b. Kan man øge valgdeltagelsen? - Analyse af mobiliseringstiltag ved kommunalvalget den 19. November 2013 [Is it Possible to Increase Voter Turnout? Analysis of Mobilization Initiatives at the November 19, 2013 Municipal Elections], Working Paper No. 3/2014, Copenhagen: Center for Voting and Parties, Department of Political Science, University of Copenhagen.

—. 2014c. Mobilisering via SMS til Europaparlamentsvalget 25. maj 2014 [Mobilization via SMS at the European Parliament Election May 25, 2014], Working Paper No. 5/2014, Copenhagen: Center for Voting and Parties, Department of Political Science, University of Copenhagen.

- 2015. Getting Out the Vote with Evaluative Thinking. American Journal of Evaluation 36 (3):389-400. Braconnier, Celine, Jean-Yves Dormagen, and Vincent Pons. 2016. Voter Registration Costs and Disenfranchisement: Experimental Evidence from France, Working Paper No. 15-098. Cambridge, MA: Harvard Business School.

Cantoni, Enrico, and Vincent Pons. 2016. Do Interactions With Candidates Increase Voter Support and Participation? Experimental Evidence from Italy, Working Paper No. 16-080. Cambridge, MA: Harvard Business School.

Enos, Ryan D., and Anthony Fowler. 2016. Aggregate Effects of Large-Scale Campaigns on Voter Turnout. Political Science Research and Methods. Published online 18 May 2016. DOI: http://dx. doi.org/10.1017/psrm.2016.21.

Fieldhouse, Edward, David Cutts, Peter John, and Paul Widdop. 2014. When Context Matters: Assessing Geographical Heterogeneity of Get-Out-The-Vote Treatment Effects Using a Population Based Field Experiment. Political Behavior 36 (1):77-97.

Foos, Florian. 2016. First Impressions - Lasting Impressions: Candidate Contact and Party Support in the 2015 UK General Election. Paper Prepared for the NYU CESS Experimental Political Science Conference 2016, New York City, NY, 19-20 February.

Foos, Florian, and Peter John. 2016. Parties Are No Civic Charities: Voter Contact and the Changing Partisan Composition of the Electorate. Conditionally accepted for publication in Political Science Research and Methods. http://www.florianfoos.net/resources/Manuscript_Foos_John.pdf.

Franco, Annie, Neil Malhotra, and Gabor Simonovits. 2014. Publication Bias in the Social Sciences: Unlocking the File Drawer. Science 345 (6203):1502-505.

Gerber, Alan S., and Donald P. Green. 2000. The Effects of Canvassing, Telephone Calls, and Direct Mail on Voter Turnout: A Field Experiment. American Political Science Review 94 (3):653-63.

2012. Field Experiments: Design, Analysis, and Interpretation. New York: WW Norton.

Giné, Xavier, and Ghazala Mansuri. 2011. Together We Will: Experimental Evidence on Female Voting Behavior in Pakistan. Policy Research Working Papers. Washington, DC: World Bank. DOI: http:// dx.doi.org/10.1596/1813-9450-5692.

Green, Donald P., and Alan A. Gerber. 2008. Get Out the Vote: How to Increase Voter Turnout, 2nd Edition. Washington, DC: Brookings Institution Press.

Green, Donald P., Alan A. Gerber, and David W. Nickerson. 2003. Getting Out the Vote in Local Elections: Results from Six Door-to-Door Canvassing Experiments. Journal of Politics 65 (4):1083-96.

Green, Donald P., Mary C. McGrath, and Peter M. Aronow. 2013. Field Experiments and the Study of Voter Turnout. Journal of Elections, Public Opinion and Parties 23 (1):27-48.

Guan, Mei, and Donald P. Green. 2006. Noncoercive Mobilization in State-Controlled Elections: An Experimental Study in Beijing. Comparative Political Studies 39 (10):1175-93.

Hansen, Jonas Hedegaard. 2016. Residential Mobility and Turnout: The Relevance of Social Costs, Timing and Education. Political Behavior 38 (4):769-91.

Jason, Daniel W., and Simon Kollerup. 2014. Dør-til-dør-kampagnens effekt på kendskab, personlige stemmer og partivalg - et felteksperiment [Door-to-Door Campaigns' Effect on Recognition, Personal Votes and Party Choice - A Field Experiment]. In Folketingsvalgkampen 2011 i perspektiv [The Campaign for Parliament 2011 in Perspective] edited by Kasper Møller Hansen and Karina Kosiara-Pedersen, 153-74. Copenhagen: DJØF-forlag. 
John, Peter, and Tessa Brannan. 2008. How Different are Telephoning and Canvassing? Results from a 'Get Out the Vote' Field Experiment in the British 2005 General Election. British Journal of Political Science 38 (3):565-74.

Karp, Jeffrey A., Susan A. Banducci, and Shaun Bowler. 2007. Getting Out the Vote: Party Mobilization in a Comparative Perspective. British Journal of Political Science 38 (1):91-112.

Matland, Richard E., and Gregg R. Murray. 2012. An Experimental Test of Mobilization Effects in a Latino Community. Political Research Quarterly 65 (1):192-205.

Nickerson, David W. 2008. Is Voting Contagious? Evidence from Two Field Experiments. American Political Science Review 102 (1):49-57.

Nyman, Pär. 2014. Door-to-Door Canvassing in the European Elections: Evidence from a Swedish Field Experiment. Uppsala: Working Paper, Department of Government, Uppsala University.

Pons, Vincent. 2016. Will a Five-Minute Discussion Change Your Mind? A Countrywide Experiment on Voter Choice in France, Working Paper No. 16-079. Cambridge, MA: Harvard Business School.

Pons, Vincent, and Guillaume Liegey. 2016. Increasing the Electoral Participation of Immigrants Experimental Evidence from France, Working Paper No. 16-094. Cambridge, MA: Harvard Business School.

Ramiro, Luis, Laura Morales, and Maria Jiménez-Buedo. 2012. The Effects of Party Mobilization on Electoral Results. An Experimental Study of the 2011 Spanish Local Elections. Paper Prepared for the 2012 International Political Science Association World Congress of Political Science, Madrid, 8-12 July. 